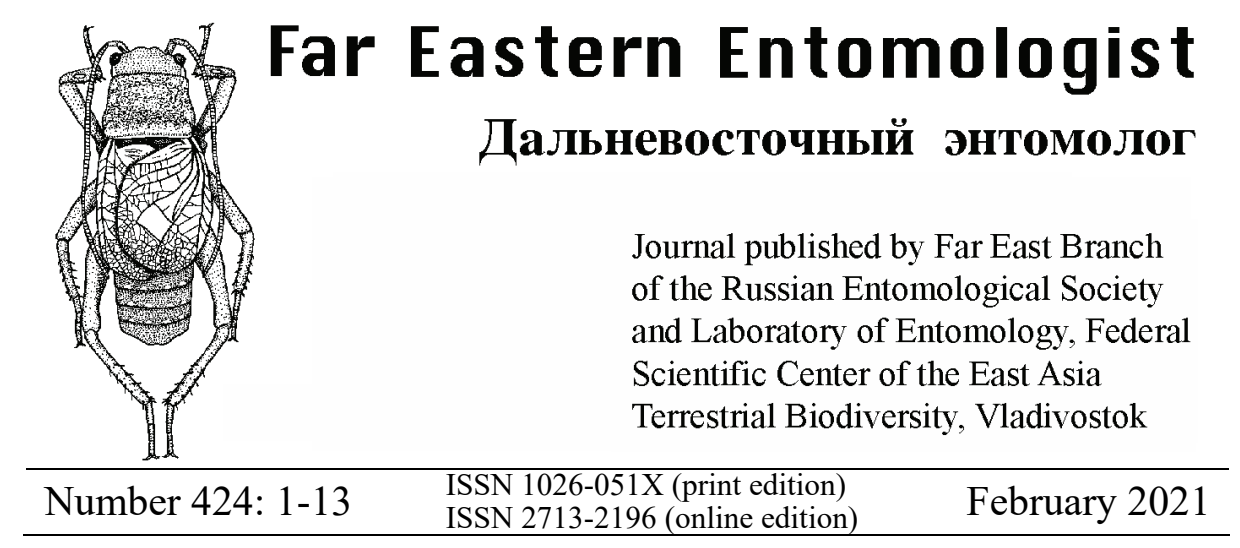

https://doi.org/10.25221/fee.424.1

http://zoobank.org/References/92EABD04-12D8-4D9A-A9DC-196AB6E7CFAD

\title{
DESCRIPTION OF TWO NEW SPECIES OF \\ CERAMBYCIDAE (COLEOPTERA) FROM NORTHWESTERN YUNNAN (CHINA)
}

$$
\text { T. Tichý }{ }^{1, *}, \text { M.-Y. } \operatorname{Lin}^{2)}
$$

1) Technical University of Ostrava, Sokolska trida 33, Ostrava, 702 00, Czech Republic. *Corresponding author, E-mail: tomas.tichy@vsb.cz

2) Key Laboratory of Zoological Systematics and Evolution, Institute of Zoology, Chinese Academy of Sciences, 1-5 Beichen West Road, Chaoyang Dist., Beijing, 100101, China.

Summary. Two new species of Cerambycidae, Ischnostrangalis ohbayashii Tichý et Lin, sp. n. (Lepturinae: Lepturini) and Anaglyptus miroshnikovi Tichý et Lin, sp. n. (Cerambycinae: Anaglyptini), are described from Yunnan province of China. The new species are compared with closely related congeners.

Key words: longicorn beetles, Cerambycinae, Lepturinae, taxonomy, new species, South China.

Т. Тихий, М.-Ю. Линь. Описание двух новых видов жуков-усачей (Соleoptera, Cerambycidae) с северо-запада провинции Юньнань (Китай) // Дальневосточный энтомолог. 2021. N 424. С. 1-13.

Резюме. Из китайской провинции Юньнань описаны два новых вида семейства Cerambycidae: Ischnostrangalis ohbayashii Tichý et Lin, sp. n. (Lepturinae: Lepturini) и Anaglyptus miroshnikovi Tichý et Lin, sp. n. (Cerambycinae: Anaglyptini). Новые виды сравниваются с близкими представителями соответствующих родов. 


\section{INTRODUCTION}

In this paper, two new species of Cerambycidae are described as new for science, one belonging to Lepturini Latreille, 1802, the other to Anaglyptini Lacordaire, 1868. Both species were discovered at relatively high elevation in primeval forests of Northwestern Yunnan in the vicinity of Yubeng village (雨崩) on the eastern slopes of sacred Tibetan mountain Kawa Gebo (Kawa Karpo) in the Meili Snow Mountain Range, part of Hengduan Mountains. This is the highest mountain of Yunnan province and it is located between two well-known parallel rivers oriented from the north to the south, Nujiang (Salween) and Lancang Jiang (Mekong). Although most of the series came from Yubeng village vicinity (i.e., Lancang valley), for each species one additional paratype from the western slopes of the mountain (i.e., Nujiang valley) was available.

The first species belongs to the genus Ischnostrangalis Ganglbauer, 1889, which was originally erected by its author as a subgenus of genus Leptura Linnaeus, 1758 for I. semenowi Ganglbauer, 1889 from Gansu. The text of Ganglbauer bears 18891890 in the centre of the title page and 1890 on its bottom so that some authors use 1890 as the year of publication. Moreover, some authors think that Ischnostrangalis was erected as a subgenus of Strangalia (e.g., Tavakilian \& Chevillotte, 2020), probably because the treatment of both genera was confusing in the past. About one hundred years later, Hayashi \& Villiers (1985) upgraded Ischnostrangalis to genus status. The genus has relatively restricted distribution and currently it comprises 12 species distributed especially in China, from Gansu across Sichuan to Yunnan and Xizang and also in Northeastern India (and possibly also Northern Myanmar).

The second species belongs to the genus Anaglyptus Mulsant, 1839, which has much larger distribution. It was originally erected by its author for two European representatives, A. gibbosus (Fabricius, 1787) and A. mysticus (Linnaeus, 1758), while the latter was subsequently designated as the type species of the genus, because of its wider distribution and availability in the collections. Currently, the genus, including its subgenera, comprises about 60 species and subspecies distributed from Western Europe to Japan, China, and Vietnam. As concerns China, new species have been describing regularly over last decades, see Viktora et al. (2013), Miroshnikov et al. (2014), Viktora \& Tichy (2015), and Viktora \& Liu (2018) for the most recent additions.

\section{MATERIAL AND METHODS}

Habitus pictures were usually taken with a Canon EOS 7D + Canon Macro 100 $\mathrm{mm}$, while genitalia pictures were taken with a large depth-of-field 3D Digital Microscope (Keyence VHX-1000C).

The holotypes of the new species are deposited in Institute of Zoology, Chinese Academy of Sciences, Beijing, China (IZCAS), while the paratypes are deposited in collections as follows: CAS - California Academy of Sciences, San Francisco, California, USA; CNO - collection of Nobuo Ohbayashi, Miura City, Japan; CTT collection of Tomáš Tichý, Opava, Czech Republic. Moreover, specimens of related 
species, including the type specimens, were studied in various museum collections, such as Muséum National d'Histoire Naturelle, Paris (France), Naturhistorisches Museum Basel (Switzerland) and the Natural History Museum, London (United Kingdom).

\section{TAXONOMY}

Subfamily Lepturinae Latreille, 1802

Tribe Lepturini Latreille, 1802

\section{Genus Ischnostrangalis Ganglbauer, 1889}

Type species: Leptura (Ischnostrangalis) semenowi Ganglbauer, 1889.

DIAGNOSIS. The genus is closely related to the genus Parastrangalis Ganglbauer, 1889 described initially also as a subgenus of Leptura in the same text (Ganglbauer, 1889). However, the current definition of Ischnostrangalis is quite strict, especially when compared to a rather broadly defined genus Parastrangalis all species of Ischnostrangalis have relatively long body with pronotum strongly constricted well behind the apical margin and elytral apices with outer spines. For more details, see, for example, Ohbayashi \& Lin (2013) or Tichý \& Viktora (2017).

The genus consists of three groups. The species described below as a new belongs to $I$. semenowi group, which can be characterized by body covered by golden pubescence and brownish-yellow elytra with black markings laterally. The second group was reviewed by Ohbayashi \& Lin (2013) and is characterized by black body and elytra with transverse yellowish fasciae (I. manipurensis Gahan, 1906 and three related species). The last group currently consists of $I$. rhododendri Holzschuh, 2011 only, a species resembling the first group, except of not so constricted pronotum, smaller size, narrower body and longer antennae and thus, approaching to some species of Parastrangalis.

\section{Ischnostrangalis ohbayashii Tichý et Lin, sp. n.}

http://zoobank.org/NomenclaturalActs/5CD5B71D-03E0-46E8-ACCD-728990ECA429

Figs 1-10

TYPE MATERIAL. Holotype: §̋, China: Yunnan, Deqin, Kawagebo, Yubeng pass, 2900-3400 m, 30.VII-2.VIII 2019 (IZCAS, IOZ(E)2224547). Paratypes (75 ${ }_{0}^{1}$, 20 을 deposited in CAS, CNO, CTT, IZCAS): $7 \hat{\jmath}, 1+$, China: Yunnan, Deqin, Kawagebo, Xidang-Yubeng pass, 3500-3800 m, 7-8.VII 2015; 14 ภ, 2 \%, China: Yunnan, Deqin, Kawagebo, Yubeng, 3300-3500 m, 13-16.VII 2018; 19 ふึ, 2 , China: Yunnan, Deqin, Kawagebo, Yubeng, 2900-3400 m, 4-6.VII 2019; 35 गิ, 14 q, China: Yunnan, Deqin, Kawagebo, Yubeng, 2900-3400 m, 30.VII-2.VIII 2019; 19, China: Yunnan, Fugong, Lishadi, $2.8 \mathrm{~km}$ W of Shibali on Shibali Road, $2750 \mathrm{~m}, 27.17405^{\circ} \mathrm{N}, 98.76722^{\circ} \mathrm{E}, 10$. VIII 2005. 


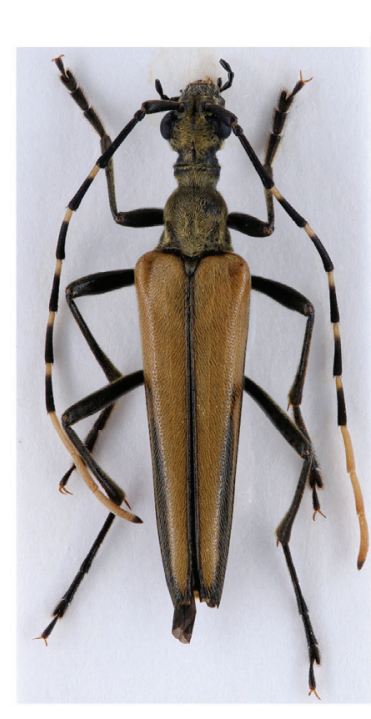

1

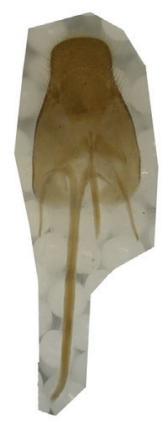

5

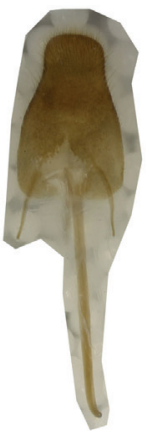

6

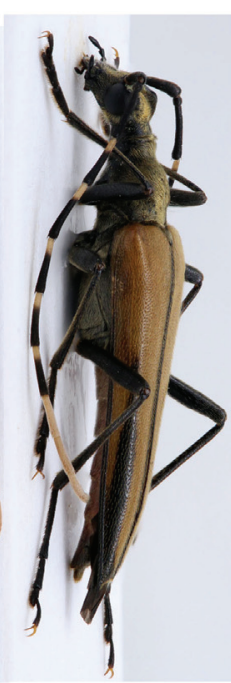

2

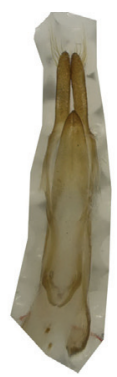

7
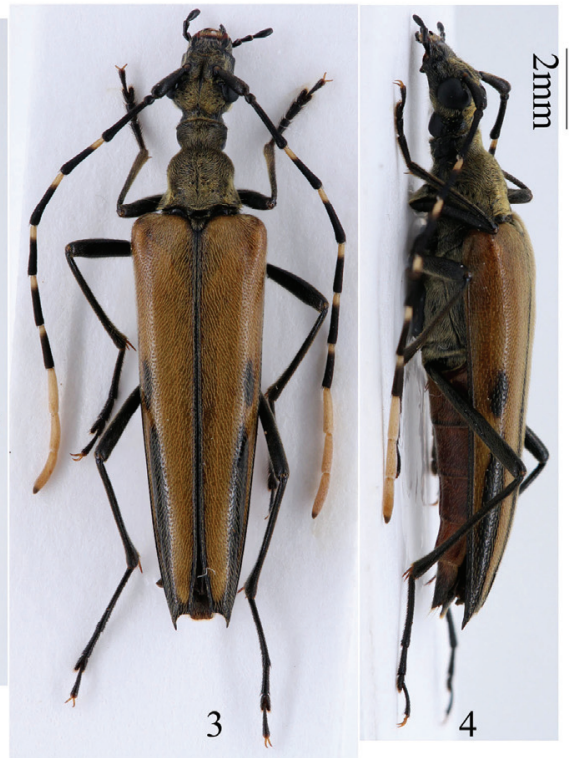

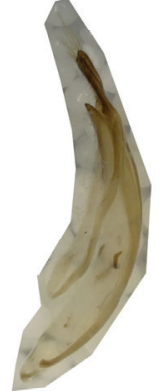

8

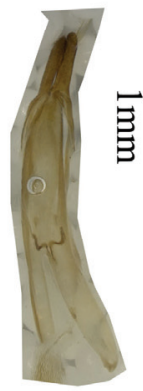

9

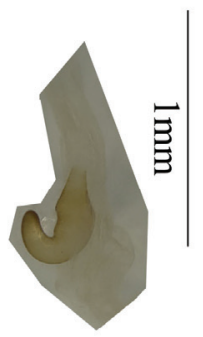

10

Figs. 1-11. Ischnostrangalis ohbayashii sp. n.: 1, 2 - male holotype; 3, 4 - female paratype; 5-10 - genitalia; 5, 6-tergite VIII and ventrites VIII, IX; 7, 8, 9 - tegmen and median lobe; $11-$ spermatheca. Scale bar for figs. $1-4=2 \mathrm{~mm}$, and for figs. 5-11 $=1 \mathrm{~mm}$.

DESCRIPTION. MALE (Figs. 1-2). Length from the tip of mandibles to the apex of elytra $12-15 \mathrm{~mm}$, humeral width about $2.8 \mathrm{~mm}$. Body black, with dull appearance because of dense golden pubescence, especially on head, pronotum and underside. Antennal segments colored as follows: 1st-3rd black, 4-8th black with light apical part, 9-11th light; the tip of the ultimate segment sometimes black. Elytra brownishyellow except black apices and lateral stripe covering up to apical $2 / 3$ of elytral length, usually interrupted in the middle of elytra; the stripe reaches the margin in apical third, otherwise well separated from the margin so that an isolated black spot is 
usually created just before the middle of elytra; however, this spot is sometimes missing. Opposed to all other species of I. semenowi group, the new species is spotless at humeri, even at sides. Whole abdomen mostly brownish-red in both sexes, though the tip partly blackish in males.

Head about as long as pronotum, slightly narrower across the eyes than pronotum at base; strongly narrowed behind the eyes, i.e., temples undeveloped, oblique; neck long; densely covered with long golden pubescence. Antennae relatively short, about the same length as body or slightly shorter; all segments of similar length, except 2 nd segment, which is very short; 5 th segment the longest. Scapus moderately thickened.

Pronotum 1.2 times as long as wide basally, relation of basal to apical width 1.5; strongly constricted at apical fourth, then inflated posteriorly and well-rounded in the middle, with less strong constriction before the base, densely covered by long golden pubescence; apical margin distinct. Longitudinal depression located in the center of the disc, rather indistinct.

Scutellum triangular, apically prolonged, densely covered by golden pubescence.

Elytra 3.4 times as long as humeral width; regularly narrowing to apices; each apex obliquely emarginate with sharply pointed outer angle and spinous inner angle; with relatively dense punctures; covered with relatively dense (not so dense when compared to head and pronotum) semi-erect pubescence of golden color.

Legs of normal size of the genus in relation to the body, long and slender, relative lengths of 1st to 3rd tarsal segments are as follows: fore tarsus $=1.7: 1.25: 1$; middle tarsus $=2.5: 1.5: 1$; hind tarsus $=4: 1.8: 1$.

Male genitalia as in Figs. 5-10. Median lobe arcuate in lateral view (Fig. 8); ventral plate apparently narrowed in the apex (Fig. 7); median struts long and relatively broad, rounded in outer apices (Fig. 9). Tegmen shorter than median lobe; parameres relatively long ( $\mathrm{ca}$. 2/7 of tegmen length) and narrow (compare with $I$. manipurensis group in Ohbayashi \& Lin, 2013), length $c a$. 5.5 times of width, apically rounded and well separated, with several long setae at outer apices, setae much shorter than parameres; ringed part with subparallel sides (without obvious elbowed part), constricted behind the middle, slightly wider again, then converging at apex. Tergite VIII (Figs. 5-6) constricted in about $2 / 3$ of its length, broadly rounded in apices, densely clothed with medium erect setae and well differs from $I$. manipurensis group as stated in Ohbayashi \& Lin (2013).

FEMALE (Figs. 3-4). Length from the tip of mandibles to the apex of elytra $12-17 \mathrm{~mm}$, humeral width about $3 \mathrm{~mm}$. Elytra much wider than in male, 3.1 times as long as broad at humeri. Antennae shorter.

DIFFERENTIAL DIAGNOSIS. The new species can be easily distinguished from all other species of $I$. semenowi group by strongly reduced black lateral stripe of elytra (i.e., basal third is completely yellowish even at sides) and the color of antennal segments (1st-3rd black, 4-8th black with light apical third, 9-11th light, except the apex of 11th). Over the years, when visiting the type locality, also several specimens of local population of I. rhododendri were collected together with the new species at flowering Viburnum sp. It can be easily distinguished from the new species by smaller and narrower body, less rounded pronotum, longer antennae, 
reddish femora (and tibiae), unicolor black antennal 1-8 segments, and not so dense golden pubescence of head and pronotum.

BIONOMY. The highest activity of the new species is relatively late in summer (second half of July), similarly to other species of I. semenowi group. It mostly visits Sambucus adnata Wallich ex Candolle because of its long flowering period, though earlier in the season it can be found on other shrubs as well (e.g., Viburnum sp.).

DISTRIBUTION. China (Yunnan).

ETYMOLOGY. Named in honor of Mr. Nobuo Ohbayashi who did significant contribution to the knowledge of this genus.

\section{Subfamily Cerambycinae Latreille, 1802 \\ Tribe Anaglyptini Lacordaire, 1868 \\ Genus Anaglyptus Mulsant, 1839}

Type species: Leptura mystica (Linnaeus, 1758).

DIAGNOSIS. The new species described below can be regarded as a clear representative of the genus Anaglyptus in its current treatment, because it differs well from type species of both related genera, i.e., from Oligoenoplus ventralis Chevrolat, 1863 by prolonged pronotum, elytra with flattened disc, basally raised tubercles and apices with outer tooth and small inner spine, etc., and from Paraclytus excultus Bates, 1884 by third antennal segment much longer than fourth, almost hairless apices with long outer tooth, etc. (see also Miroshnikov, 2014).

The genus Anaglyptus Mulsant, 1839 was separated into three subgenera in the catalogue of Palaearctic Cerambycidae (Hubweber et al., 2010). Although the distinction of Akajimatora Kusama et Takakuwa, 1984 with its four species can be regarded as stable (Bi \& Niisato, 2018), the separation of Aglaophis J. Thomson, 1857 from Anaglyptus Mulsant, 1839 remains unsolved.

\section{Anaglyptus miroshnikovi Tichý et Lin, sp. $\mathrm{n}$.}

http://zoobank.org/NomenclaturalActs/D46D6CF9-E6D2-4BC1-A5C6-9F3011E99536

Figs $11-14,25-30$

TYPE MATERIAL. Holotype: $\hat{O}$, China: Yunnan, Deqin, Kawagebo, Yubeng,

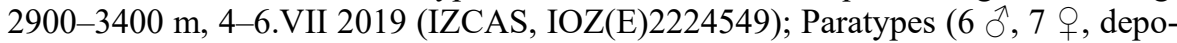
sited in CAS, CTT, IZCAS): $5 \hat{\varnothing}, 6$, the same data as holotype; 1 , the same data as holotype, except 3300-3500 m, 13-16.VII 2018; 10, China: Yunnan, Gaoligong Shan, Nujiang, Nujiang State Nature Reserve, No. 12 Bridge Camp area, $16.3 \mathrm{~km}$ W of Gongshan, $27.71503^{\circ} \mathrm{N}, 98.50244^{\circ}$ E, 2755 m, 15-19.VII 2000.

DESCRIPTION. MALE (Figs. 11-12). Length from the tip of mandibles to the apex of elytra $8-9.5 \mathrm{~mm}$, humeral width about $2 \mathrm{~mm}$. Body black, appendages reddish-brown except swollen part of femora, head reddish-brown except between the eyes; elytra partly in basal third, centrally and widely in apex also reddish-brown. Antennae with appressed whitish pubescence, segments $7-9$ almost completely, the 
other segments only basally. Elytra with three whitish fasciae as follows (elytra under fasciae generally reddish-brown): from scutellum along the suture to $1 / 5$ of the length and bent outwards to the lateral margin, broad median one from suture reaching almost lateral margin with unclear delimitation, preapical one. Most of the

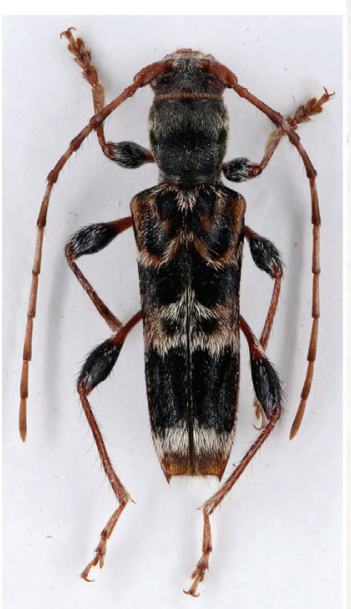

11

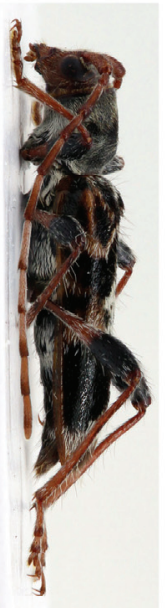

12

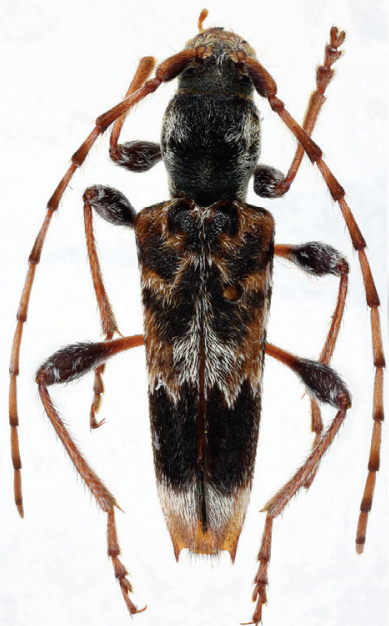

15

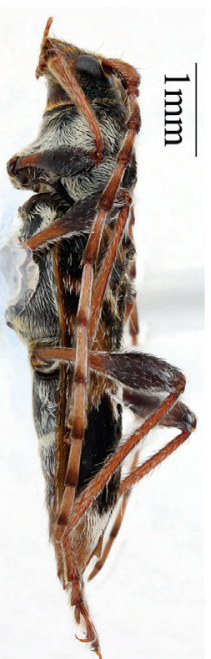

16

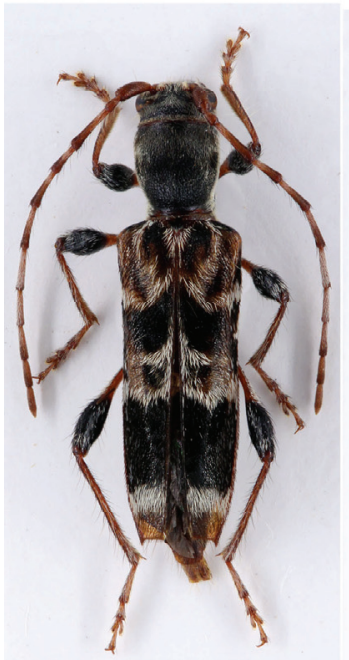

13

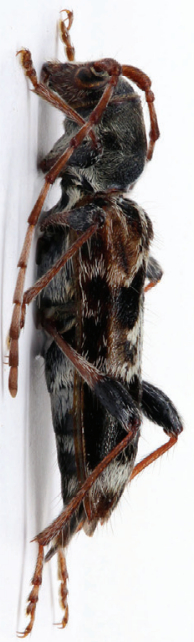

14

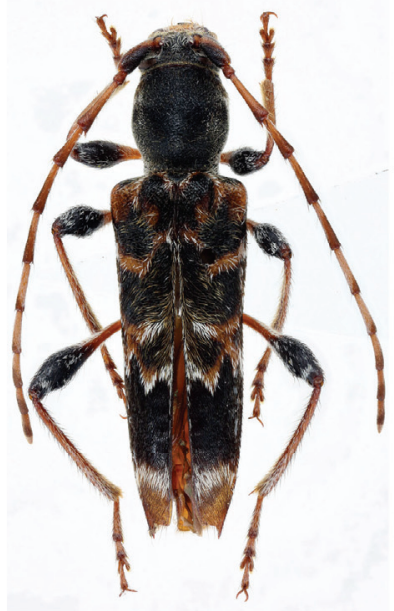

17

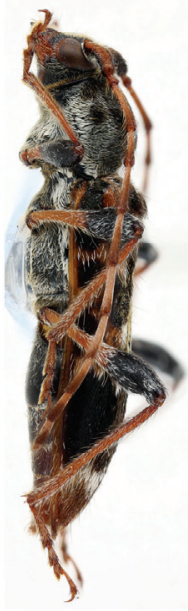

18

Figs. 11-18: Anaglyptus spp.: 11-14-A. miroshnikovi sp. n.: 11, 12 - male holotype; 13, 14 - female paratype: 15-18 - A. vicinulus Holzschuh, 1999: 15, 16 - male from Shaanxi; $17,18-$ female from Beijing. Scale bar $=1 \mathrm{~mm}$. 
pronotum covered with appressed whitish pubescence, dense and long at sides and underside, rather sparse on the disk but often forming clear transverse hairless spot in the middle (i.e., black). Underneath the body also with appressed long dense whitish pubescence.

Head short, with well developed, widely separated antennal tubercles; across the eyes almost as wide as pronotum at its widest point. Antennae relatively long, slightly extend the apex of elytra; all segments of normal length of the genus - 2nd segment is the shortest, but apparently longer than broad; 3rd segment longer than the following two $(1.5 \times 4$ th, $1.15 \times 5$ th $)$, about as long as 6 th or 7 th. Apical part of antennal segments with inner spines as follows: 3rd segment with relatively long spine, 4th segment with very short spine, no spine apparent at 5th segment. Scapus moderately thickened with clear punctures.

Pronotum barely longer than wide; rounded at sides, widest in apical third, apparently narrowed basally, constricted; flat (longitudinally) on top of the disc, sharply decreasing only at base.

Scutellum triangular, with short pubescence.

Elytra about 2.5 times as long as humeral width; regularly narrowing to apices; each apex truncated, but with long outer tooth and indistinct inner spine; with relatively dense punctures.

Legs of normal size of the genus in relation to the body, metafemora does not reach elytral apices, all femora claviform; 1st segment of hind tarsi 1.35 times as long as following two combined.

Male genitalia as in Figs. 25-29. Median lobe arcuate in lateral view (Fig. 28); ventral plate sharply narrowed to apex (Fig. 27); median struts long and relatively broad, extends for more than one half of median lobe. Tegmen much shorter than median lobe; parameres very short and wide, apically rounded, broadly separated, with many short setae and a few long setae at apex, long setae more than twice of parameres in length; ringed part extends for more than $3 / 4$ of tegmen, rounded in the widest portion, converging at apex. Tergite VIII (Figs. 25-26) transverse, largely rounded from base to apices, apex slightly emarginated, clothed with short erect setae.

FEMALE (Figs. 13-14). Length from the tip of mandibles to the apex of elytra 8-10 $\mathrm{mm}$, humeral width about $2 \mathrm{~mm}$. Elytra preapically much wider than in male. Antennae shorter than body. Color without any distinct differences from males.

MATERIAL USED FOR COMPARISON. Anaglyptus vicinulus Holzschuh, 1999: $1 \delta^{\Uparrow}$ (Figs. 8a, 8b), China: Shaanxi, Huayin, Huashan, $34.4971^{\circ}-34.4934^{\circ} \mathrm{N}$, $110.0932^{\circ}-110.0812^{\circ}$ E, 770-1618 m, 6.VI 2007, leg. M.Y. Lin (IZCAS, IOZ(E) 1896967); 1ठ̄, 1q, China: Shanxi, Yong-ji, Wulao peak, 6-18.V 2007, 1-6.VI 2011 (CTT); $100 \AA \hat{\delta} \&$, China: Henan, Funiushan, N Neixiang, Baotianman, 10-12.V 2016, 14-17.V 2018, 23-25.V 2019 (CTT); 1 ㅇ (Figs. 9a, 9b), Beijing, Mentougouqu, Qingshuizhen, Xiaolongmen, 39.96466 ${ }^{\circ}-39.95005^{\circ} \mathrm{N}, 115.4358^{\circ}-115.4857^{\circ} \mathrm{E}$, 739-1117 m, 6.V 2007, leg. HL. Shi \& Y. Liu (IZCAS, IOZ(E) 1896965). 


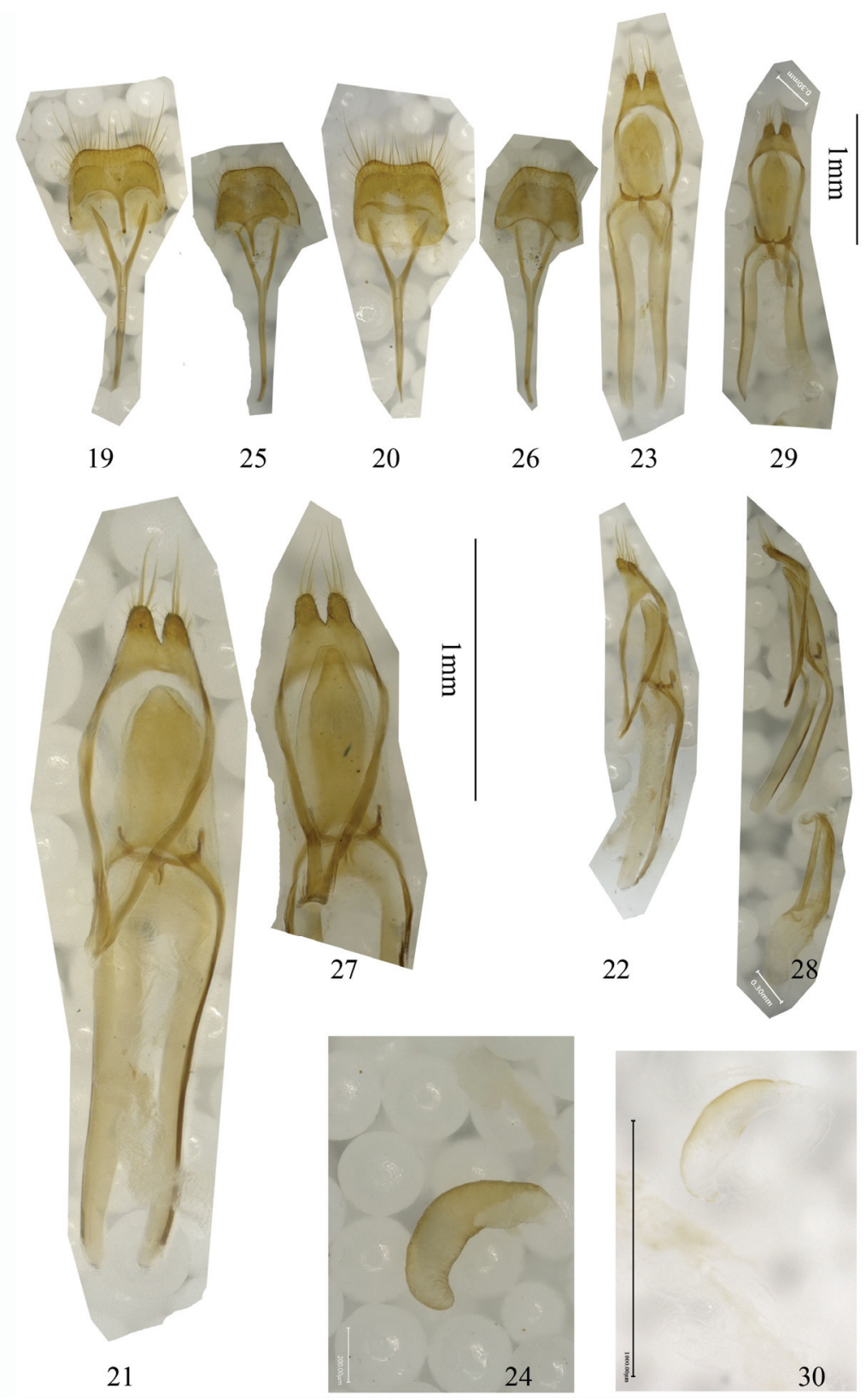

Figs. 19-30. Genitalia of Anaglyptus spp.: 19-24 - A. vicinulus Holzschuh, 1999; 25-30A. miroshnikovi sp. n.; 19, 20, 25, 26 - tergite VIII and ventrites VIII, IX; 21-23, 27-29tegmen and median lobe (ventral, lateral and dorsal view); 24, $30-$ spermatheca. Scale bar = $1 \mathrm{~mm}$. 
DIFFERENTIAL DIAGNOSIS. The new species belongs to the group of reddish-brown species with white transverse fasciae on elytra and rather rounded pronotum, A. kanssuensis Ganglbauer, 1889 group, within which it belongs to subgroup A (alphabetically).

Subgroup A. Apex of elytra reddish, preapical whitish fasciae.

1) A. confusus Holzschuh, 1999 - described from Xizang; a larger species with much longer elytra with different kind of pubescence, which is not so light, convex pronotum with a postmedian keel and relatively long spine at $3^{\text {rd }}$ antennal segment.

2) A. rufobasalis Tippmann, 1955 - currently in subgenus Aglaophis, described from Fujian; probably the smallest species of the group, apparently differs by longer spine at 3rd antennal segment, slightly longer and less rounded pronotum with clear keel in the middle, generally reddish base of elytra without black areas, postbasal fasciae of whitish pubescence and reddish-brown elytral marking rather straight (not curved as in the new species).

3) A. vicinulus Holzschuh, 1999 (Figs. 15-18) - known from Gansu and Sichuan in the west to Beijing and Henan in the east; the most similar species by colour; it differs through the pronotum, which is more globular, convex on top, highest just before base with apparent keel in $A$. vicinulus, while almost flat on top and sharply going down at base in the new species; more rounded at sides in $A$. vicinulus, while little more straight in the new species; with rather four separated hairless spots on disc of pronotum in $A$. vicinulus, while with apparently long appressed whitish hairs in the new species, especially in apical third and thus often with contrasting transverse black fasciae. Basal part of elytra with strongly elevated tubercles (not so apparent in the new species); not so oval body; different orientation of pubescence at sides and underside (apparent especially at pronotum - rather transverse in A. vicinulus, while mostly longitudinal in the new species); different genitalia as in Figs. 19-24 (parameres generally short, but longer and narrowly separated when compared to the new species; apex of dorsal plate of median lobe (Fig. 21) much less protruding compared with the new species (Fig. 27); tergite VIII (Figs. 19-20) in comparison to the new species almost parallel at sides and relatively shortly rounded in apices, with apparent emargination).

Subgroup B. Apex of elytra largely light (grayish to whitish).

4) A. gressitti Holzschuh, 1999 - a species which can be also very small; with apical part of elytra widely covered by whitish pubescence and longer antennae with apparent spine at 3rd segment.

5) A. kanssuensis Ganglbauer, 1889 - widely greyish apex of elytra, rather globular pronotum and less oval body; spine at 3rd segment of antennae rather short.

6) A. petrae Viktora et Liu, 2018 - the only other species of this group known from Yunnan; it easily differs due to apex of elytra fully covered by whitish pubescence, larger size, longer elytra and dark appearance - elytra are missing reddishbrown parts, antennae are completely dark, legs mostly (except basis of femora) black.

7) A. producticollis Gressit, 1951 - currently in subgenus Aglaophis, greyish elytral apices and globular pronotum as in A. kanssuensis; long spine at 3rd antennal segment and relatively dark appearance (dark antennal segments 1 to 6 and legs). 
8) A. tersus Viktora et Tichý, 2015 - antennae much longer than body in males, pronotal pubescence forming two large dark spots and quite different elytral pubescence - besides three dirty white and rather broad and strait transverse bands (posthumeral, postmedian and preapical) it has also humeral and rather isolated median spots; no black areas.

Further species known from Yunnan and Xizang provinces have either robust yellowish to green body with blackish isolated spots or clearly demarked transverse fasciae (A. annulicornis (Pic, 1933), A. flavus Viktora, Tichý et Rapuzzi, 2013, A. tichyi Miroshnikov, Bi et Lin, 2014), robust, rounded reddish-brown body with isolated dark brown spots (A. ambiguus Holzschuh, 1992), or prolonged body (and pronotum) with very different pubescence (A. arcanus Miroshnikov, Bi et Lin, 2014, A. elegantulus Miroshnikov, Bi et Lin, 2014, A. qijuni Viktora et Liu, 2018).

BIONOMY. Most of the specimens were collected on flowering Viburnum sp. together with Ischnostrangalis ohbayashii sp. nov.

DISTRIBUTION. China (Yunnan).

ETYMOLOGY. Named in honor of Mr. Alexandr Miroshnikov (Krasnodar, Russia) who did significant contribution to the knowledge of the tribe Anaglyptini.

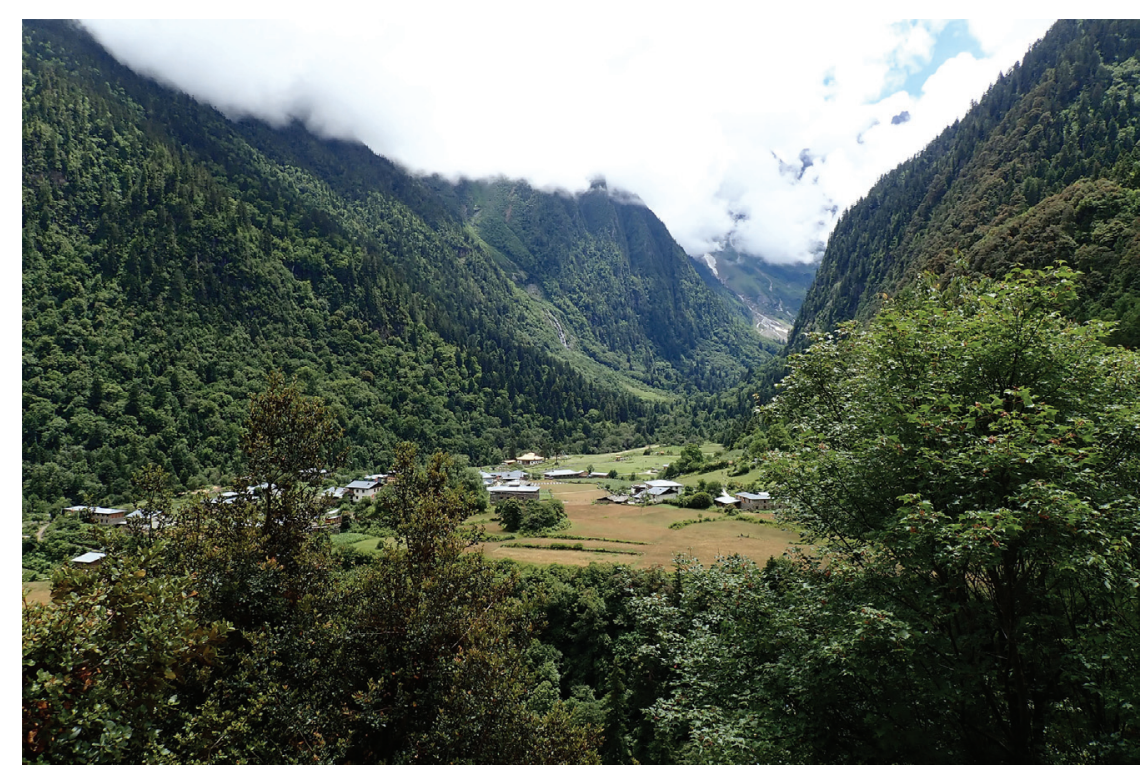

Fig. 31. Yubeng village (Deqin, Yunnan) - collecting locality of both new species.

\section{CONCLUSION}

Both species were discovered at the same place of Northwestern Yunnan. The type locality (Fig. 31) is relatively isolated and far away as concerns the distribution of closely related species - the nearest known localities of the representatives of $I$. semenowi group are about $400 \mathrm{~km}$ away on eastern side of the Hengduan Mountains, 
while for closely related species of Anaglyptus the nearest localities are even more distant. Hence, proper exploration of further areas in between might bring additional new species for both genera.

\section{REFERENCES}

Bi, W.-X. \& Niisato, T. 2018. Taxonomic Study on the Subgenus Anaglyptus (Akajimatora) Kusama \& Takakuwa, 1984 (Coleoptera, Cerambycidae) from China. Elytra (New Series), $8(1): 75-79$.

Chevrolat, L.A.A. 1863. Clytides d'Asie et d'Océanie. Mémoires de la Société Royale des Sciences de Liège, 18(4): 253-350.

Fabricius, J.C. 1787. Mantissa insectorum sistens eorum species nuper detectas adiectis characteribus genericis, differentiis specificis, emendationibus, observationibus Hafniae, Proft 1.

Gahan, C.J. 1906. The Fauna of British India, Including Ceylon and Burma. Coleoptera. Vol. I. (Cerambycidæ). C.T. Bingham, London.

Ganglbauer, L. 1889. Insecta, a cl. G. N. Potanin in China et in Mongolia novissime lecta. VII. Buprestidae, Oedemeridae, Cerambycidae. Horae Societatis Entomologicae Rossicae, 24: $21-85$.

Gressitt, J.L. 1951. Longicorn Beetles of China. Longicornia: 1-667.

Hayashi, M. \& Villiers, A. 1985. Revision of the Asian Lepturinae (Coleoptera: Cerambycidae) with special reference to the type specimens' inspection. Part I. Bulletin of the Osaka Jonan Women's Junior College, 19-20(1): 1-75.

Holzschuh, C. 1992. 57 neuen Bockkäfern aus Asien, vorwiegend aus China, Thailand und Vietnam (Coleoptera: Cerambycidae). Schriftenreihe der Forstlichen Bundesversuchanstalt (FBVA-Berichte), 69: 1-63.

Holzschuh, C. 1999. Beschreibung von 71 neuen Bockkäfern aus Asien, vorwiegend aus China, Laos, Thailand und Indien (Coleoptera, Cerambycidae). Schriftenreihe der Forstlichen Bundesversuchanstalt (FBVA-Berichte), 110: 1-64.

Holzschuh, C. 2011. Beschreibung von 69 neuen Bockkäfern und 6 neuen Gattungen aus Asien, vorwiegend aus Borneo, China, Laos und Thailand (Coleoptera, Cerambycidae). Entomologica Basiliensa et Collectionis Frey, 33: 249-328.

Hubweber, L., Löbl, I., Morati, J. \& Rapuzzi, P. 2010. Cerambycidae. Taxa from the People's Republic of China, Japan, and Taiwan, pp. 84-334. In: Löbl I. \& Smetana A. (ed.): Catalogue of Palaearctic Coleoptera, Vol. 6. Chrysomeloidea. Stenstrup, Apollo Books.

Kusama, K. \& Takakuwa, M. 1984. The Longicorn Beetles of Japan in Color. Japanese Society of Coleopterology, Kôdansha, Tokyo.

Lacordaire, J.T. 1868. Histoire Naturelle des Insectes. Genera des Coléoptères ou exposé méthodique et critique de tous les genres proposés jusqu'ici dans cet ordre d'insectes. Paris. Librairie Encyclopédique de Roret.

Latreille, P.-A. 1802. Histoire Naturelle, générale et particulière des Crustacés et des Insectes. Ouvrage faisant suite à l'Histoire Naturelle générale et particulière, composée par Leclerc de Buffon, et rédigée par C. S. Sonnini, membre de plusieurs Sociétés savants. Imprimerie F. Dufart, Paris.

Linnaeus, C. 1758. Systema naturce per regna tria naturce secundum classes, ordines, genera, species, cum characteribus, differentiis, synonymis, locis. Systema naturae (Editio 10) Laur, Salvius, Holmiae. 
Miroshnikov, A. 2014. A review of the genus Paraclytus Bates, 1884, with the description of a new species from China (Coleoptera: Cerambycidae). P. 73-132. In: Konstantinov, A.S., Slipinski, S.A. \& Solodovnikov, A.Yu. (Eds.). Advances in Studies on Asian Cerambycids (Coleoptera: Cerambycidae). Papers by Alexandr I. Miroshnikov, dedicated to the memory of Dr. Judson Linsley Gressitt. KMK Scientific Press Ltd., Krasnodar, Moscow.

Miroshnikov, A., Bi, W.-X. \& Lin, M.-Y. 2014. New or little-known species of the genus Anaglyptus Mulsant, 1839 (Coleoptera: Cerambycidae) from China. Caucasian Entomological Bulletin, 10(2): 255-259.

Mulsant, E. 1839. Histoire Naturelle des Coléoptères de France. Longicornes. Maison, Paris.

Ohbayashi, N. \& Lin, M.-Y. 2013. Studies on the Chinese Lepturinae (Coleoptera: Cerambycidae), II. Notes on the Genus Ischnostrangalis Ganglbauer, 1890. P. 41-56. In: Lin, M.-Y. \& Chen, C.-C. (Eds). In memory of Mr. Wenhsin Lin. Formosa Ecological Company, Taiwan.

Ohbayashi, N., Niisato, T., \& Wang, W.-K. 2004. Studies on the Cerambycidae (Coleoptera) of Hubei Province, China: Part I. Elytra 32(2), 451-470.

Pic, M. 1933. Espèces et variétés Nouvelles. Matériaux Pour Servir à L'étude des Longicornes, 11(1): 4-7.

Tavakilian, G. \& Chevillotte, H. 2020. Base de Données Titan sur les Cerambycidés ou Longicornes. Available from: http://titan.gbif.fr/index.html (visited 20/05/2020)

Thomson, J. 1857. Description de cérambycides nouveaux ou peu connus de ma collection. Archives Entomologiques, 1: 291-320.

Tichý, T. \& Viktora, P. 2017. Two new species of Lepturini (Coleoptera: Cerambycidae) from Hubei province of China. Studies and Reports. Taxonomical Series, 13(2): 499509.

Tippmann, F. 1955. Zur Kenntnis der Cerambycidenfauna Fukiens (Süd-Ost-China). Koleopterologische Rundschau, 33(1-6): 88-137.

Viktora, P. \& Liu, B. 2018. New Anaglyptini from China (Coleoptera, Cerambycidae, Cerambycinae). Folia Heyrovskyana (Series A), 26(1): 151-160.

Viktora, P. \& Tichý, T. 2015. A contribution to the knowledge of Anaglyptini Lacordaire, 1869 of Sichuan (China) with description of two new species (Coleoptera, Cerambycidae, Cerambycinae). Les Cahiers Magellanes (NS), 17: 6-19.

Viktora, P., Tichý, T. \& Rapuzzi, P. 2013. Description of a new species of the genus Anaglyptus Mulsant, 1839 from Tibet (Coleoptera, Cerambycidae, Cerambycinae, Anaglyptini). Les Cahiers Magellanes (NS), 13: 80-83. 